\title{
Fluid Flow of Polar and Less Polar Liquids through Modified Poplar Wood
}

\author{
Hamid R. Taghiyari ${ }^{1, *(D)}$, Hanieh Abbasi ${ }^{1}$, Holger Militz ${ }^{2}$ (D) and Antonios N. Papadopoulos ${ }^{3, *(D)}$ \\ 1 Wood Science and Technology Department, Faculty of Materials Engineering \& New Technologies, \\ Shahid Rajaee Teacher Training University, Tehran 16788-15811, Iran; habbasi968@gmail.com \\ 2 Wood Biology and Wood Products, Georg-August-University Göttingen, 37077 Göttingen, Germany; \\ hmilitz@gwdg.de \\ 3 Laboratory of Wood Chemistry and Technology, Department of Forestry and Natural Environment, \\ International Hellenic University, GR-66100 Drama, Greece \\ * Correspondence: htaghiyari@sru.ac.ir (H.R.T.); antpap@for.ihu.gr (A.N.P.)
}

Citation: Taghiyari, H.R.; Abbasi, H.; Militz, H.; Papadopoulos, A.N. Fluid Flow of Polar and Less Polar Liquids through Modified Poplar Wood. Forests 2021, 12, 482. https:// doi.org/10.3390/f12040482

Academic Editors: Lina Nunes, Dennis Jones and Bruno Esteves

Received: 24 February 2021

Accepted: 12 April 2021

Published: 14 April 2021

Publisher's Note: MDPI stays neutral with regard to jurisdictional claims in published maps and institutional affiliations.

Copyright: (C) 2021 by the authors. Licensee MDPI, Basel, Switzerland. This article is an open access article distributed under the terms and conditions of the Creative Commons Attribution (CC BY) license (https:// creativecommons.org/licenses/by/ $4.0 /)$.

\begin{abstract}
Fast-growing species often have a low natural durability and can easily be attacked by fungi and insects, and therefore it is often better to preserve them before use. Permeability is a physical property in porous media that significantly affects the penetration of water- and oil-based preservatives into the texture of wood. In the present study, the specific gas permeability and liquid permeability to water and kerosene in poplar wood (Populus nigra var. betulifolia) were measured. The poplar trees were grown in plots with two spacings of $3 \times 4 \mathrm{~m}$ and $3 \times 8 \mathrm{~m}$. Separate sets of specimens were also thermally modified in order to examinethe effects of this modification on gas and liquid permeability values. The results showed higher gas permeability in specimens grown in the plot with wider spacing $(3 \times 8 \mathrm{~m})$, which was attributed to their larger vessel diameter. Kerosene demonstrated significantly higher permeability in comparison to water. This was attributed to the polar nature of water molecules, which tend to make stronger bonds with wood cell-wall polymers, ultimately delaying the movement of water through vessel elements. Thermal modification had an increasing effect on specific gas permeability. The increase was attributed to cracks that occur in the pits and wood cell wall during thermal modification, making way for the easier flow of fluids. Decreased wettability caused by thermal modification resulted in a significant increase in both water and kerosene permeability values.
\end{abstract}

Keywords: permeation; porous media; solid wood; liquid and gas permeability; thermal modification

\section{Introduction}

Wood is a renewable construction material with many applications. Though it has several advantages over other construction materials, it also suffers from some inherent drawbacks, like dimensional instability and susceptibility to some bio-organisms [1-5]. Some of these drawbacks can be mitigated through preservation techniques that involve the penetration of preservatives and fire retardants into the porous structure of solid wood. The preservation of wood is considered a practical way to extend the service life of fastgrowing wood species, which are generally categorized as perishable. In this connection, better knowledge on the permeability of wood species to different fluids would provide the wood preservation industry with a better outlook as to the type of preservative to use.

Moreover, the use of several technologies to thermally modify wood has been rapidly increasingthroughout the world, as these technologies represent an environmentally friendly method to address some of the abovementioned drawbacks. One particular advantage of this method is that usually no chemicals are involved in the process. Thermal modification can specially be used to improve dimensional stability in wood and to improve biological resistance to wood-deteriorating fungi [5-8]. 
The present study was conducted to primarily investigate the specific gas permeability and liquid permeability of water and kerosene in poplar wood, as it is a popular fastgrowing species in Iran and around the world. A comparison between different fluids (gas, water and kerosene) was then performed in order to reveal their relationship and their favorability for preservation purposes. The study continued with the preparation of separate sets of specimens to be thermally modified in order to further investigate to what extent their gas and liquid permeability values were affected.

\section{Materials and Methods}

\subsection{Specimen Procurement}

Six ten-year-old poplar trees (Populus nigra var. betulifolia) were randomly selected from a site located in Karaj, Iran $\left(35^{\circ} 48^{\prime} \mathrm{N}, 50^{\circ} 54^{\prime} \mathrm{W}, 1300 \mathrm{~m}\right.$ above sea level), with an annual rainfall and average annual temperature of about $230 \mathrm{~mm}$ and $13.7{ }^{\circ} \mathrm{C}$, respectively. The deep soil was an alluvial sandy clay. It was moderately alkali with a $\mathrm{pH}$ of 8 . The topsoil contained an average nitrogen concentration of $0.07 \%(0-25 \mathrm{~cm})$. Poplar trees were planted in $1200 \mathrm{~m}^{2}$ plots. Trees were planted with two initial spacings, $3 \times 4 \mathrm{~m}$ and $3 \times 8 \mathrm{~m}$. From each initial spacing, three trees were randomly selected. A disk with $10-\mathrm{cm}$ thickness was cut from each tree and dried to a moisture content of $8-9 \%$. Twelve cylindrical longitudinal specimens (17 $\mathrm{mm}$ in diameter) were cut from each disk, equally scattered from pith to bark, to cover all parts of the disks.

\subsection{Gas Permeability Measurement}

To date, a variety of techniques and methods have been developed to measure gas permeability in solid wood and wood-based materials [9-12]. A recently developed apparatus was used in the present study, designed and built on the basis of the falling-water volume-displacement method (Figure 1). This apparatus is equipped with a seven-phase electronic-time-measurement device using a display with milli-second precision [13]. Before permeability measurement, specimens were kept in a conditioning room $\left(25{ }^{\circ} \mathrm{C} \pm 2{ }^{\circ} \mathrm{C}\right.$, and $40 \% \pm 3 \%$ relative humidity) for ten weeks to reach a moisture content of $8 \% \pm 0.2 \%$. The mean value of three measurements for each specimen was considered final for the calculation of superficial gas permeability, using Equations (1) and (2). Then, the superficial gas permeability coefficients were multiplied by the viscosity of air to finally obtain the specific gas permeability $\left(K_{g}=k_{g} \mu\right)$.

$$
\begin{gathered}
k_{g}=\frac{V_{d} C L\left(P_{a t m}-0.074 \bar{z}\right)}{t A(0.074 \bar{z})\left(P_{a t m}-0.037 \bar{z}\right)} \times \frac{0.760 m H g}{1.013 \times 10^{6} P a} \\
C=1+\frac{V_{r}(0.074 \Delta z)}{V_{d}\left(P_{a t m}-0.074 \bar{z}\right)}
\end{gathered}
$$

where:

$k_{g} \quad=$ longitudinal superficial permeability $\left(\mathrm{m}^{3} \mathrm{~m}^{-1}\right)$,

$V_{d}=\pi r^{2} \Delta z(\mathrm{r}=$ radius of measuring tube $(\mathrm{m}))\left(\mathrm{m}^{3}\right)$,

$C=$ correction factor for gas expansion as a result of the change in static head and viscosity of water,

$L \quad=$ length of wood specimen (m),

$P_{a t m}=$ atmospheric pressure $(\mathrm{m} \mathrm{Hg})$,

$\bar{z} \quad=$ average height of water over the surface of the reservoir during the period of measurement (m),

$t \quad=$ time $(\mathrm{s})$,

$A \quad=$ cross-sectional area of wood specimen $\left(\mathrm{m}^{2}\right)$,

$\Delta z \quad=$ change in height of water during time $\mathrm{t}(\mathrm{m})$,

$V_{r} \quad=$ total volume of apparatus above point 1 (including volume of hoses) $\left(\mathrm{m}^{3}\right)$. 


\subsection{Liquid Permeability Measurement}

RILEM test tubes were used for the measurement of liquid permeability, according to RILEM Commission 25, PEM, Test Method II.4, 1154 (International Union of Laboratories and Experts in Construction Materials, Systems, and Structures). Tests were carried out according to ASTM Standard E-514 (ASTM, West Conshohocken, PA, USA, 2018) and under the stipulated laboratory conditions. Tubes were fixed in an apparatus with milli-second precision to measure two liquid permeability values (Figure 2). Two liquids were used in this project, water $\left(\mathrm{H}_{2} \mathrm{O}\right)$ and kerosene $\left(\mathrm{C}_{12} \mathrm{H}_{26}\right)$. Liquid permeability time values consisted of the first drop (the time that it took the first drop to fall off the bottom of the specimen) and the 50-mm decreasing time (the time that it took the level of liquid in the RILEM tube to decrease by fifty millimeters, which is by definition equal to $6.6 \mathrm{CC}$ of liquid). The liquid permeability, as determined by the drop of the liquid column in the RILEM test tube, was registered and reported at five column levels of ten millimeterseach.

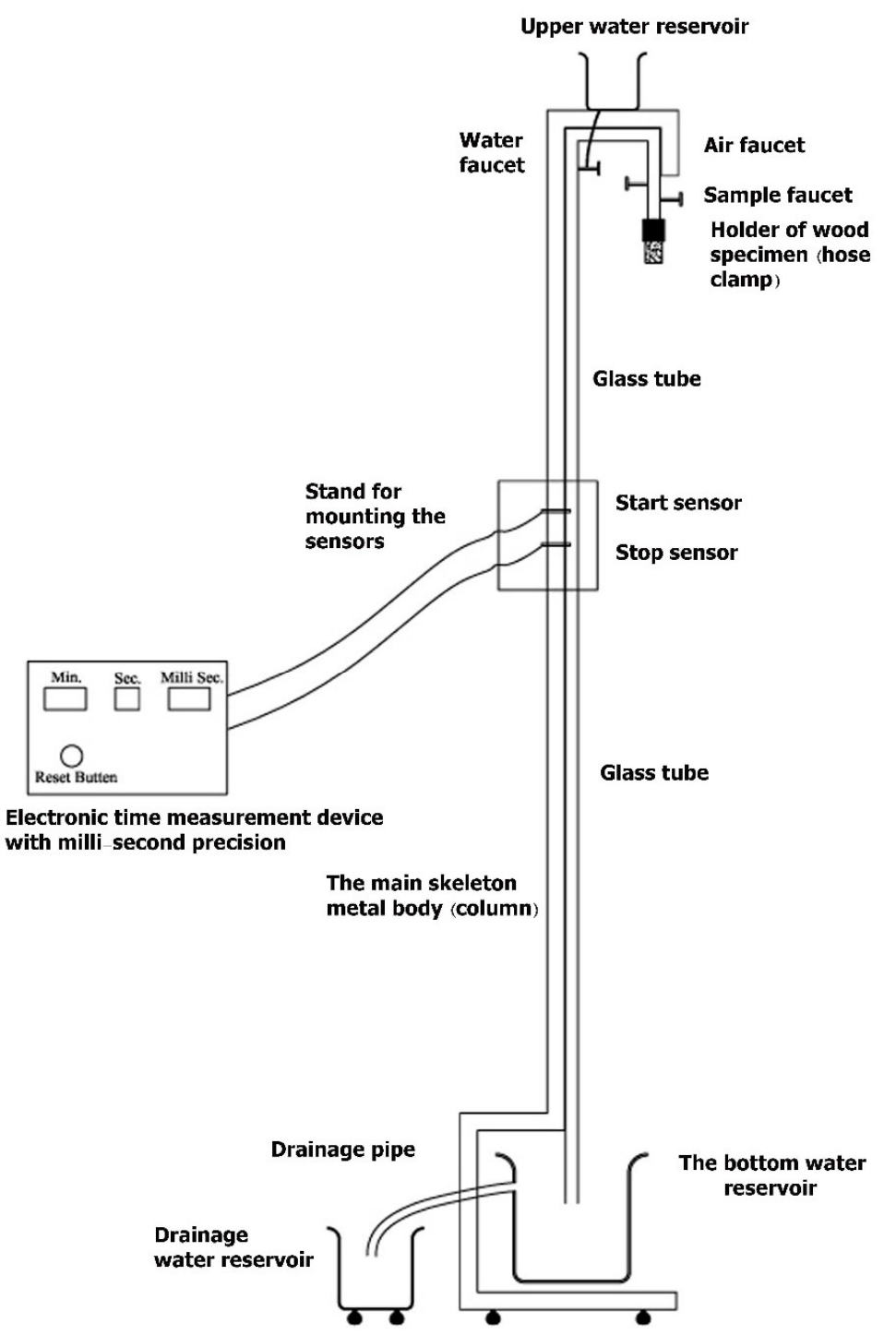

Figure 1. Schematic of the specific gas permeability measurement apparatus, equipped with a singlephase electronic time measurement device with milli-second precision (approved under certificate No. 47022; issued by The Iranian Research Organization for Scientific and Technology) [10,13]. 


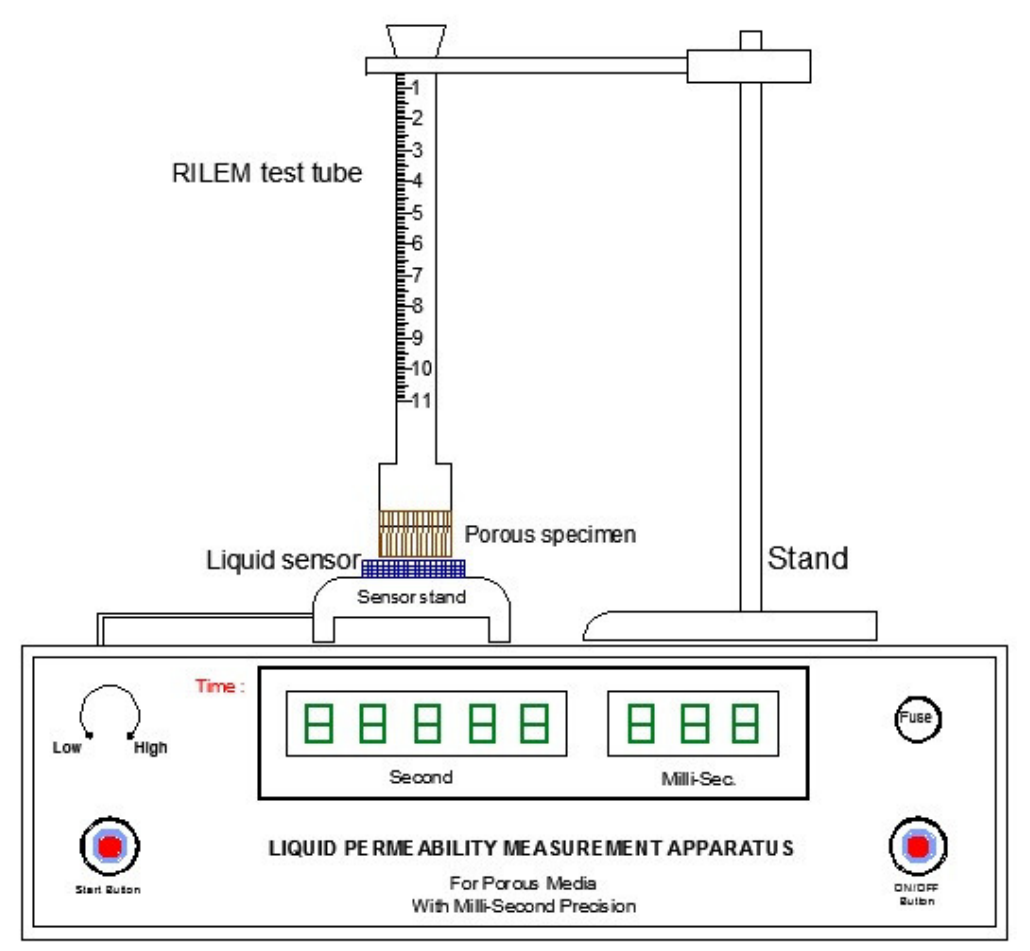

Figure 2. Liquid permeability apparatus designed and built in accordance with the RILEM test method II.4 specifications. The apparatus is equipped with a time-measuring device with millisecond precision $[5,14]$.

\subsection{Thermal Modification}

As to the non-destructive nature of specific gas permeability measurements, the gas permeability of specimens to be thermally modified was measured twice, that is, both before and after thermal modification. This way, the effects of thermal modification on gas permeability would be reported. Having beentested for the first time, they were randomly arranged in the middle tray of a laboratory oven. Strips of three-layer plywood were prepared to be put under the specimens to avoid direct contact with the metal tray. Specimens were heated at $185^{\circ} \mathrm{C}$ for four hours. After the modification, they were again kept in a conditioning room $\left(25^{\circ} \mathrm{C} \pm 2{ }^{\circ} \mathrm{C}\right.$ and $40 \% \pm 3 \%$ relative humidity) for four more weeks, along with the untreated specimens. Then, specific gas permeability was measured for the second time, followed by liquid permeability measurement.

\subsection{Statistical Analysis}

Two-way analysis of variance (ANOVA) was carried out to discern significant differences at a $95 \%$ level of confidence between the four treatments in each plot, using the SAS software program (version 9.2) (2010). Groupings were made between treatments using the Duncan Multiple Range test. Regression and hierarchical cluster analyses were carried out using SPSS/18 (2009). For cluster analysis, Ward methods with squared Euclidean distance intervals were used. Cluster analysis categorizes different treatments based on more than one property, in the present case based on six properties (including liquid permeability of the first drop, and five stages of the decreasing liquid level in the RILEM test tube). This reveals the similarities and dissimilarities of treatments based on all properties involved.

\section{Results and Discussion}

The results showed that specific gas permeability values in poplar wood were $11.13 \pm 8.9$ $\left(\times 10^{-13} \mathrm{~m}^{3} \mathrm{~m}^{-1}\right)$ and $14.25 \pm 8.2\left(\times 10^{-13} \mathrm{~m}^{3} \mathrm{~m}^{-1}\right)$ in plots with $3 \times 4 \mathrm{~m}$ and $3 \times 8 \mathrm{~m}$ spacings, respectively. The standard deviation was high in both plots. High variability in the specific gas permeability of some solid wood specimens is quite natural, and it is considered an inherent property $[14,15]$. This high variability in permeability is further 
translated into high variability in liquid uptake, which has repeatedly been reported in different poplar wood species [16,17]. The cited authors demonstrated parts of specimens that were fully impregnated, next to which were spots with no impregnation. The higher gas permeability in poplar specimens in the plot with wider spacing $(3 \times 8 \mathrm{~m})$ was related to higher vessel lumen in this plot, as was reported previously [18]. In this connection, a positive significant relationship was found between the increase in spacing with the increase in vessel lumen diameter $[18,19]$.

The results of liquid permeability measurements, as determined by the first drop from the bottom of the specimens, demonstrated the significantly higher liquid permeability of kerosene in comparison to water in both spacings. This higher liquid permeability of kerosene was translated into lower time-values, as shown in Figure 3A,B. The higher kerosene permeability was attributed to its significantly lower adsorption energy on cellulose, in comparison to the adsorption energy of water molecules. It was previously reported that the adsorption energy of water and kerosene molecules on cellulose were -1.42 and $-0.80(\mathrm{eV})$, respectively [14]. Moreover, the adsorption distances of water and kerosene molecules on cellulose were 1.69 and $2.98(\AA)$, respectively [14]. Both the adsorption energy and adsorption distance of water and kerosene molecules on cellulose indicated the higher tendency of water molecules to make stronger and more stable bonds with cellulose polymer in the wood cell wall. Therefore, the movement of water molecules along the vessel lumen is significantly delayed, ultimately increasing the time it takesfor the liquid to pass through vessels. However, kerosene molecules have lower adsorption energy and are conveyed through vessels more easily, although kerosene molecules are significantly larger in size in comparison to water molecules.

The measurement of liquid permeability, as determined by the time it took for the water column in the RILEM test tube to drop by $50 \mathrm{~mm}$, similarly demonstrated the higher liquid permeability of kerosene (that is, lower time-values in graphs) in comparison to water (Figure 4A,B). As time passed and the liquid column in RILEM tube gradually dropped down from the initial level (the starting point) to the fifth level (fifty millimetres below the starting point), the time significantly increased for water. This was attributed to the swelling of wood in every specimen as a result of the absorption of liquid $[20,21]$. The swelling of wood, in turn, is hypothesized to push the vessel lumen to shrink inward, leaving less space for water to pass through. Still, the measurement of vessel properties (particularly, vessel diameter) at different moisture contents should be studied in order to come to a final and firm conclusion in this regard. Kerosene showed a similar increasing trend, though the slope was significantly flattened.

Weight measurements before and after thermal modification revealed weight losses of $5.2 \%$ and $5.5 \%$ for plots with $3 \times 4 \mathrm{~m}$ and $3 \times 8 \mathrm{~m}$ spacing, respectively. Thermal modification increased gas permeability in plots with $3 \times 4 \mathrm{~m}$ spacing by $18 \%$. The amount of increase in gas permeability was only $4 \%$ in the plot with $3 \times 8 \mathrm{~m}$ spacing. The increase in specific gas permeability was attributed to cracks and checks that occur in the pits and wood cell wall during the thermal process. These cracks, though very small in size, acted as new ways and bypasses for air to pass through, eventually increasing specific gas permeability.

Thermal modification substantially decreased liquid permeability to water, as determined by the first drop from the bottom side of the specimens. This decrease in water permeability, which is translated into a drastic increase in the time-values of the graphs, was partly attributed to alteration of cell-wall polymers and their hydroxyl groups (Figure 3A,B), preventing water molecules from being easily absorbed on the surface layer of vessel elements and moving forward along them. Moreover, wettability in different solid wood species was reported to decrease as a result of thermal modification [10,22-24]. This decrease in wettability and the change in the contact angle between water and modified wood also partially delayed water from moving through the vessel elements. Liquid permeability values, as determined by the time it took for the water column to drop down 
in the RILEM tube, exhibited similar decreasing trends caused by thermal modification (Figure 4A,B).

Regression analysis indicated a negative and mostly insignificant relationship between specific gas permeability and both liquid permeability values in all treatments (Table 1). With regard to the negative sign in the relationship between these two properties, this is quite natural, as the higher specific gas permeability is translated into a shorter time for both liquids to be conveyed through vessel elements, as illustrated in Figure 3A,B and Figure 4 A,B. Similar negative values were reported in previous studies $[10,25,26]$. However, with regard to the statistically insignificant relationship, and the fact that no particular trend was observed in the R-squared values, it should be noted that opposing factors were involved in this study. On one side, thermal modification resulted in an increase in gas permeability; but from the other side, the same modification method caused theliquid permeability time to significantly increase. The opposing results of thermal modification on gas and liquid permeability time caused the R-squared values to be rather low and statistically insignificant. Still, it should be noted that the plot with wider spacing $(3 \times 8 \mathrm{~m})$ demonstrated more cases of high and significant R-squared values in comparison to the plot with lower spacing $(3 \times 4 \mathrm{~m})$. With due consideration to the difference in vessel diameter of the two plots, it can be deduced that wider vessel diameter can significantly affect the correlation between specific gas permeability and liquid permeability values. However, this must be elaborated in greater detail and with a wider range of vessel diameters in order to come to a firm conclusion.

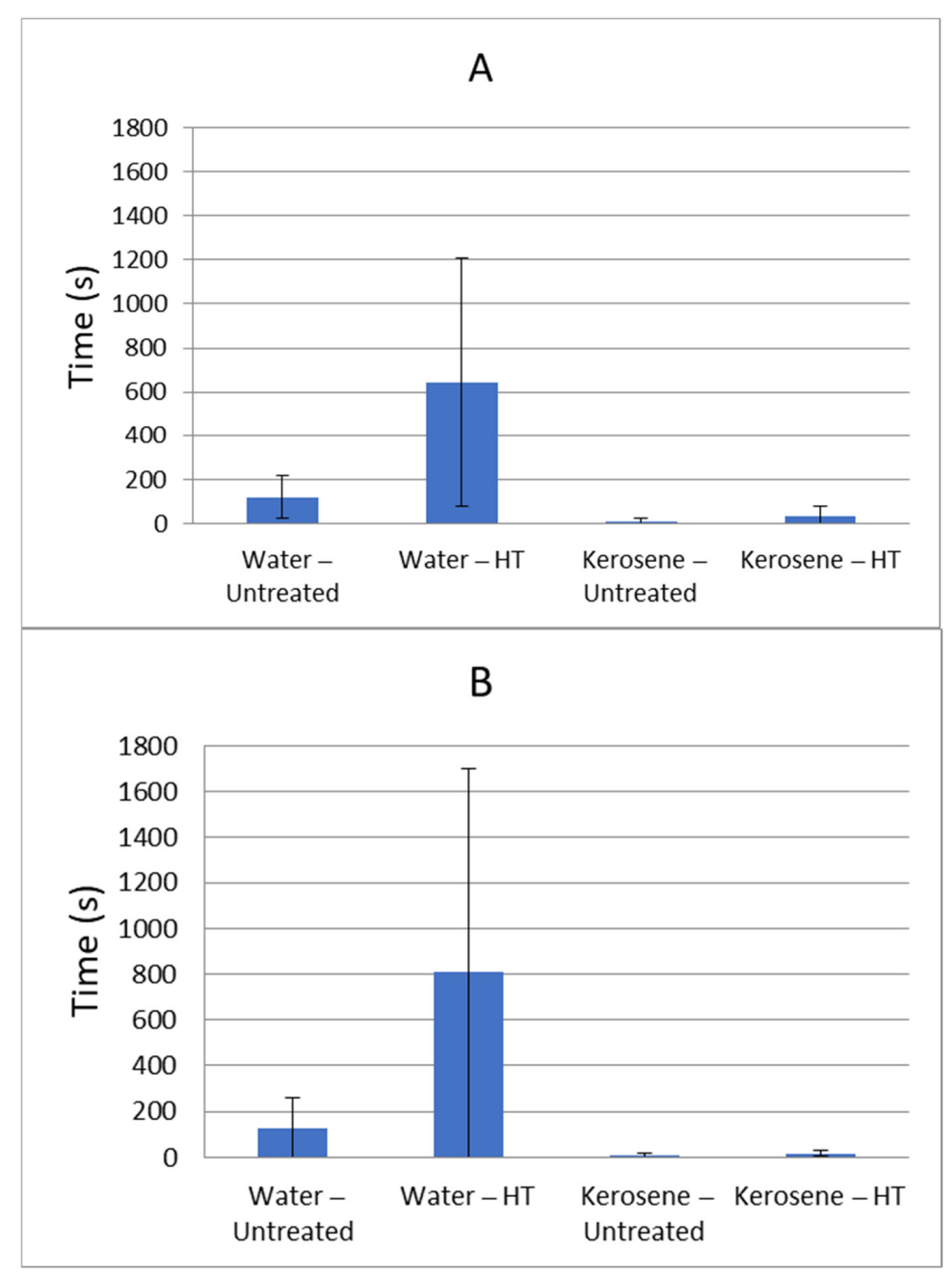

Figure 3. Liquid permeability, as determined by the first drop from the bottom of the specimens, in Populus nigra var. betulifolia with $3 \times 4 \mathrm{~m}$ spacing $(\mathbf{A})$ and $3 \times 8 \mathrm{~m}$ spacing $(\mathbf{B})(\mathrm{HT}=$ heat-treated). 


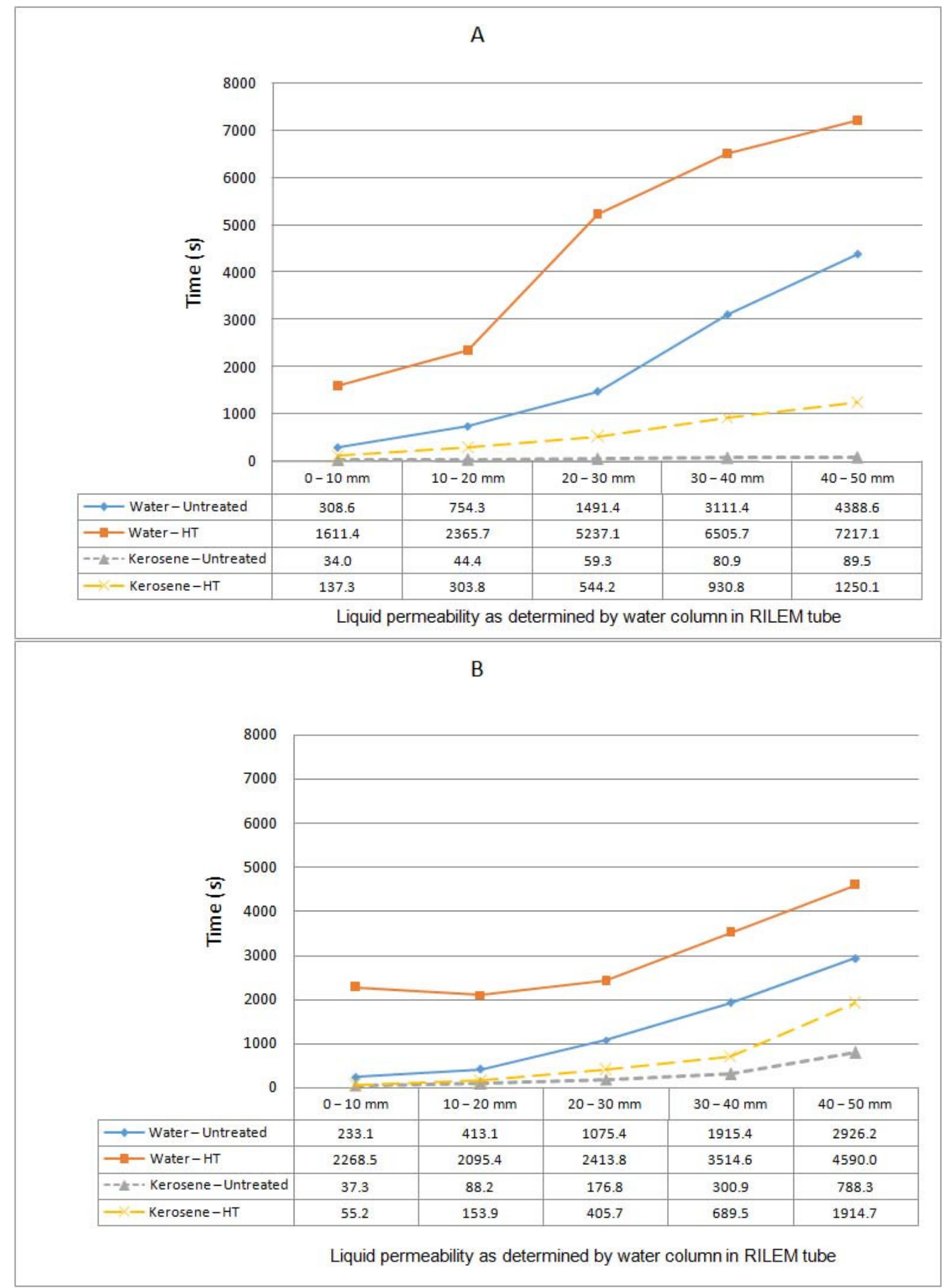

Figure 4. Liquid permeability, as determined by the time it took for the water column to drop in the RILEM tube, in Populus nigra var. betulifolia with $3 \times 4 \mathrm{~m}$ spacing $(\mathbf{A})$ and $3 \times 8 \mathrm{~m}$ spacing $(\mathbf{B})(\mathrm{HT}=$ heat-treated).

Cluster analysis of the eight treatments (consisting of two plots with different spacing and four treatments of each) based on the two liquid permeability values of water and kerosene demonstrated distinct close clustering of the four treatments measured by kerosene, regardless of the spacing or thermal modification (Figure 5). This implied that thermal modification of poplar wood would not make a substantial impact when poplar wood is planned to be preserved by oil-based preservatives. However, the two thermally modified treatments, the liquid permeability of which were measured by water, were 
remotely clustered from all the other six treatments. It can therefore be deduced that the alteration in hydroxyl groups of cell-wall polymers, as well as the change in wettability, caused by thermal modification would substantially affect the way water as a polar liquid interacts with the altered wood, and how it is conveyed through vessel elements. It is to be noted that the findings presented here were achieved under low pressure. The results under vacuum pressures and at industrial scales are to be investigated in future research.

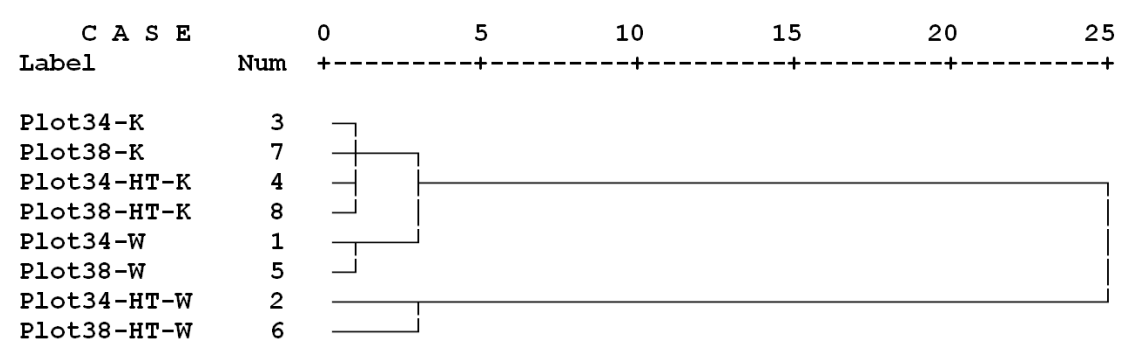

Figure 5. Cluster analysis of the eight treatments (consisting of the two plots with different spacings and the four treatments of each) based on liquid permeability determined by the first drop from the bottom of the RILEM tube, and by the dropping of the water column in the tube in five different stages (Plot34 = plot with spacing $3 \times 4 \mathrm{~m}$; Plot38 = plot with spacing $3 \times 8 \mathrm{~m}$; K = permeability measured by kerosene; $\mathrm{W}=$ permeability measured by water; $\mathrm{HT}=$ heat-treated specimens).

Table 1. Regression analysis between specific gas permeability and liquid permeability as determined by the first drop, and by the time it took for the water column to drop in the RILEM tube, in Populus nigra var. betulifolia with $3 \times 4 \mathrm{~m}$ spacing (A) and $3 \times 8 \mathrm{~m}$ spacing $(\mathrm{B})$.

\begin{tabular}{|c|c|c|c|c|c|c|c|c|}
\hline & \multirow{2}{*}{ Treatments } & & \multirow{2}{*}{ First Drop } & \multicolumn{5}{|c|}{ Water Column in the Tube } \\
\hline & & & & 0-10 mm & $10-20 \mathrm{~mm}$ & $20-30 \mathrm{~mm}$ & $30-40 \mathrm{~mm}$ & $40-50 \mathrm{~mm}$ \\
\hline \multirow{4}{*}{$\begin{array}{l}\text { Spacing } \\
3 \times 4 \mathrm{~m}\end{array}$} & \multirow{2}{*}{ Water } & Unheated & $-0.81 *$ & -0.56 & -0.45 & -0.43 & -0.42 & -0.41 \\
\hline & & Heat-treated & -0.56 & -0.72 & -0.61 & -0.53 & -0.53 & -0.53 \\
\hline & \multirow{2}{*}{ Kerosene } & Unheated & -0.62 & -0.47 & -0.50 & -0.60 & -0.63 & -0.61 \\
\hline & & Heat-treated & -0.65 & -0.51 & -0.52 & -0.51 & -0.51 & -0.51 \\
\hline \multirow{4}{*}{$\begin{array}{l}\text { Spacing } \\
3 \times 8 \mathrm{~m}\end{array}$} & \multirow{2}{*}{ Water } & Unheated & -0.53 & $-0.57^{*}$ & -0.54 & $-0.57^{*}$ & -0.54 & -0.50 \\
\hline & & Heat-treated & $-0.68^{*}$ & $-0.82 * *$ & $-0.58^{*}$ & -0.52 & -0.43 & -0.44 \\
\hline & \multirow{2}{*}{ Kerosene } & Unheated & $-0.85^{* *}$ & $-0.74 *$ & $-0.78^{* *}$ & -0.74 * & -0.74 * & $0.68 *$ \\
\hline & & Heat-treated & -0.65 & -0.55 & -0.60 & -0.53 & -0.52 & -0.49 \\
\hline
\end{tabular}

** Correlation is significant at the 0.01 level. * Correlation is significant at the 0.05 level.

\section{Conclusions}

The effects of thermal modification on the specific gas permeability and liquid permeability of water and kerosene in poplar wood (Populus nigra var. betulifolia), cultivated in plots with two spacings $(3 \times 4 \mathrm{~m}$ and $3 \times 8 \mathrm{~m})$, were studied here. The results demonstrated the higher specific gas permeability of poplar wood grown in the plot with wider spacing $(3 \times 8 \mathrm{~m})$, which was attributed to the larger vessel diameter in the wood. Liquid permeability measurements indicated significant higher permeability of kerosene in comparison to water, regardless of the plot or wood treatment. The lower adsorption energy of kerosene molecules on cellulose in the wood cell-wall resulted in weaker and less stable bonds being formed between kerosene and wood; thus, eventually this fluid was conveyed more easily and rapidly through vessel elements in comparison to water. Thermal modification resulted in an increase in specific gas permeability, which was attributed to checks and cracks that occur in the pits and the wood cell wall during the thermal process, making new channelsand bypasses for fluids to pass through. However, thermal modification substantially decreased water permeability in both plots. This was 
partially attributed to the alteration in the structures of cell-wall polymers, as well as the change in the wettability of the wood. Kerosene permeability was influenced by thermal modification to a lesserdegree than water permeability. It was concluded that oil-based preservatives would be preferable in cases in whichsolid wood is to be thermally modified.

Author Contributions: Methodology, H.R.T., H.A. and A.N.P.; validation, H.R.T., H.M. and A.N.P.; investigation, H.R.T. and H.A.; writing - original draft preparation, H.R.T., H.M. and A.N.P.; writingreview and editing, H.R.T., H.M. and A.N.P.; visualization, H.R.T.; supervision, H.R.T. and A.N.P. All authors have read and agreed to the published version of the manuscript.

Funding: This research received no external funding.

Institutional Review Board Statement: Not applicable.

Informed Consent Statement: Not applicable.

Data Availability Statement: The data presented in this study are available on request from the corresponding author.

Acknowledgments: We appreciate the kind efforts of Ali Azim-Bagirad for his technical electronic consultation on the design and building of the gas permeability apparatus), as well as Alexander von Humboldt Stiftung (Bonn, Germany).

Conflicts of Interest: The authors declare no conflict of interest.

\section{References}

1. Papadopoulos, A.N.; Taghiyari, H.R. Innovative Wood Surface Treatments Based on Nanotechnology. Coatings 2019, 9, 866. [CrossRef]

2. Maresi, G.; Oliveira Longa, C.M.; Turchetti, T. Brown rot on nuts of Castanea sativa Mill: An emerging disease and its causal agent. iForest 2013, 6, 294-301. [CrossRef]

3. De Medeiros, F.C.M.; Gouveia, F.N.; Bizzo, H.R.; Vieira, R.F.; Del Menezzi, C.H.S. Fungicide activity of essential oils from Brazilian Cerrado specie against wood decay fungi. Int. Biodeterior. Biodegrad. 2016, 114, 87-93. [CrossRef]

4. Mantanis, G.; Papadopoulos, A.N. Reducing the thickness swelling of wood based panels by applying a nanotechnology compound. Eur. J. Wood Wood Prod. 2010, 68, 237-239. [CrossRef]

5. Taghiyari, H.R.; Tajvidi, M.; Taghiyari, R.; Mantanis, G.I.; Esmailpour, A.; Hosseinpourpia, R. Chapter 19-Nanotechnology for wood quality improvement and protection. In Nanomaterials for Agriculture and Forestry Application; Elsevier: Amsterdam, The Netherlands, 2020. [CrossRef]

6. Hill, C.A.S. Wood Modification-Chemical, Thermal and Other Processes; John Wiley and Sons Ltd.: West Sussex, UK, 2006.

7. Taghiyari, H.R.; Norton, J.; Tajvidi, M. Chapter 14-Effects of Nano-materials on Different Properties of Wood-Composite Materials. In Bio-Based Wood Adhesives: Protection, Characterization, and Testing; CRC Press/Taylor \& Francis Group: Boca Raton, FL, USA, 2017.

8. Repellin, V.; Guyonnet, R. Evaluation of heat treated wood swelling by differential scanning calorimetry in Relation with Chemical Composition. Holzforschung 2007, 59, 28-34. [CrossRef]

9. Shi, S.H.Q. Diffusion model based on Fick's second law for the moisture absorption process in wood fiber-based composites: Is it suitable or not? Wood Sci. Technol. 2007, 41, 645-658. [CrossRef]

10. Taghiyari, H.R.; Moradi Malek, B. Effect of heat treatment on longitudinal gas and liquid permeability of circular and squareshaped native hardwood specimens. Heat Mass Transf. 2014, 50, 1125-1136. [CrossRef]

11. Siau, J.F. Transport Processes in Wood; Springer: Berlin/Heidelberg, Germany; GmbH \& Co. KG: Berlin, Germany, 2011.

12. Dermoe, D.; Zillig, W.; Carmeliet, J. Variation of measured cross-sectional cell dimensions and calculated water vapor permeability across a single growth ring of spruce wood. Wood Sci. Technol. 2012, 46, 827-840. [CrossRef]

13. USPTO. Gas Permeability Measurement Apparatus. U.S. Patent Patent Number 8079249 B2, 2009,20 December 2011.

14. Esmailpour, A.; Taghiyari, H.R.; Majidi, R.; Babaali, S.; Morrell, J.J.; Mohammadpanah, B. Effects of adsorption energy on air and liquid permeability of nanowollastonite-treated medium-density fiberboard. IEEE Trans. Instrum. Meas. 2021, 70, 1-8. [CrossRef]

15. Taghiyari, H.R.; Avramidis, S. Specific gas permeability of normal and nanosilver-impregnated solid wood species as influenced by heat-treatment. Maderas Ciencia y Tecnología 2019, 21, 89-96. [CrossRef]

16. Lutz, H. Microscopic Analysis of the Heterogeneous Uptake of Impregnating Agents by Selected Hybrid Poplar (Populus spp.). Master's Thesis, Georg-August University, Göttingen, Germany, 2020.

17. Brune, N. Macroscopic Studies on the Variable Impregnability of Selected Poplar Hybrids. Bachelor's Thesis, Georg-August University, Göttingen, Germany, 2020.

18. Taghiyari, H.R.; Efhami, D.; Karimi, A.N.; Pourtahmasi, K. Effect of initial spacing on gas permeability of Populus nigra Var. betulifolia. J. Trop. For. Sci. 2011, 23, 305-310. 
19. Mantanis, G.I.; Young, R.A. Wetting of wood. Wood Sci. Technol. 1997, 31, 339. [CrossRef]

20. Dinwoodie, J.M. Timber: Its Nature and Behavior; Van Nostrand Reinhold Company Ltd.: Wokingham, UK, 1981.

21. Walker, J.C.F.; Butterfield, B.G.; Langrish, T.A.G.; Harris, J.M.; Uprichard, J.M. Primary Wood Processing: Principles and Practise; Chapman \& Hall Ltd.: London, UK, 1993.

22. Kúdela, J. Wetting of wood surface by a liquids of a different polarity. Wood Res. 2014, 59, 11-24.

23. Oberhofnerová, E.; Pánek, M. Surface wetting of selected wood species by water during initial stages of weathering. Wood Res. 2016, 61, 545-552.

24. Papp, E.A.; Csiha, C.; Makk, A.N.; Hofmann, T.; Csoka, L. Wettability of wood surface layer examined from chemical change perspective. Coatings 2020, 10, 527. [CrossRef]

25. Taghiyari, H.R. Nano-zycosil in MDF: Gas and liquid permeability. Eur. J. Wood Wood Prod. 2013, 71, 353-360. [CrossRef]

26. Taghiyari, H.R.; Kalantari, A.; Ghorbani, M.; Bavaneghi, F.; Akhtari, A. Effects of fungal exposure on air and liquid permeability of nanosilver- and nanozincoxide-impregnated Paulownia wood. Int. Biodeterior. Biodegrad. 2015, 105, 51-57. [CrossRef] 